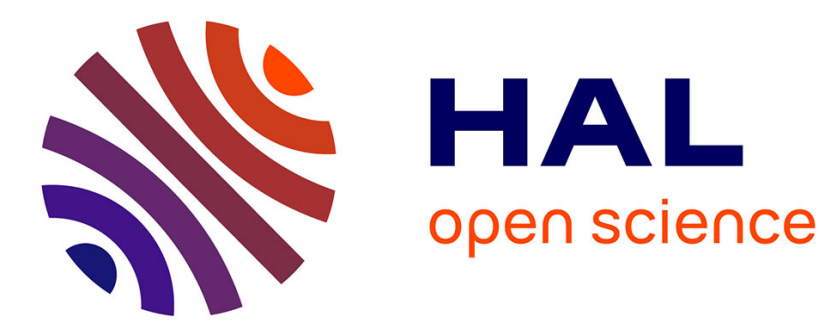

\title{
Perspective of CO2 capture \& storage (CCS) development in Vietnam: Results from expert interviews
}

Hoang Anh Nguyen Trinh, Minh Ha-Duong

\section{To cite this version:}

Hoang Anh Nguyen Trinh, Minh Ha-Duong. Perspective of CO2 capture \& storage (CCS) development in Vietnam: Results from expert interviews. International Journal of Greenhouse Gas Control, 2015, 37, pp.220-227. 10.1016/j.ijggc.2015.03.019 . hal-01137656

\section{HAL Id: hal-01137656 https://hal.science/hal-01137656}

Submitted on 1 Apr 2015

HAL is a multi-disciplinary open access archive for the deposit and dissemination of scientific research documents, whether they are published or not. The documents may come from teaching and research institutions in France or abroad, or from public or private research centers.
L'archive ouverte pluridisciplinaire HAL, est destinée au dépôt et à la diffusion de documents scientifiques de niveau recherche, publiés ou non, émanant des établissements d'enseignement et de recherche français ou étrangers, des laboratoires publics ou privés. 


\title{
Perspective of $\mathrm{CO}_{2}$ Capture \& Storage (CCS) development in
}

\section{Vietnam: Results from expert interviews}

\author{
Trinh Hoang Anh Nguyen ${ }^{\mathrm{a}, \mathrm{b}}$,, Minh Ha-Duong ${ }^{\mathrm{a}, \mathrm{b}}$ \\ a) Centre International de Recherche sur l'Environnement et le Développement, \\ CIRED/CNRS, 45 bis, avenue de la Belle Gabrielle, 94130 Nogent-sur-Marne, France

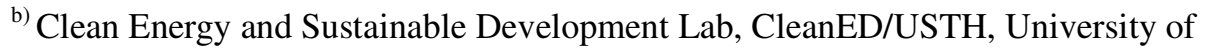 \\ Science and Technology of Hanoi, 18 Hoang Quoc Viet, Hanoi, Viet Nam \\ *)the corresponding author: hoanganhelec@gmail.com
}

\begin{abstract}
This paper summarizes expert opinions regarding crucial factors that may influence Vietnam's future use of carbon capture and storage (CCS) based on face-to-face interviews in December 2013 with 16 CCS-related experts from the Vietnamese government, research institutes, universities and the energy industrial sector. This study finds that financial incentives and climate policy are the most important factors for the development of CCS technologies in Vietnam in the next two decades. Financial incentives involve direct subsidies from the government, such as tax exemptions for land use and the importation of CCS-related equipment. In addition, all the experts agree that international financial support is important to initiate a large deployment of CCS technologies in Vietnam by implementing demonstrative/pilot projects to prove CCS's working efficiency.
\end{abstract}

Key-words: $\mathrm{CO}_{2}$ capture and storage, expert interview, Vietnam, emission reduction, low carbon electricity

\section{Contents}

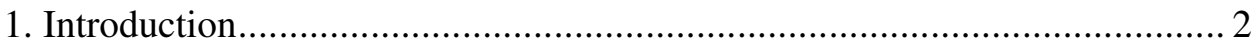

2. Literature on the experts' views on CCS policy ........................................ 3

3. Description of interview method and themes ........................................... 4

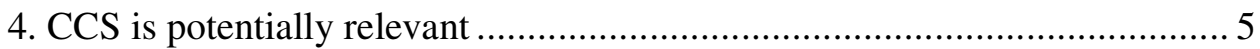

5. Obstacles to CCS/CR deployment in Vietnam ..................................... 7

6. Solutions to advance CCS in Vietnam...................................................... 9 
7. Discussion....

8. Conclusions

References

Annex

\section{Introduction}

Carbon capture and storage (CCS) is an important technological option to reduce global $\mathrm{CO}_{2}$ emissions. The control of global $\mathrm{CO}_{2}$ emissions would be more effective if developing countries building new fossil-fuel power plants, such as Vietnam, participated more actively in the world CCS development plan. Yet at present, CCS is not attractive to Vietnam because the technology is expensive and no emission targets have been set. This work aims to gather expert opinions on barriers to and incentives for CCS and capture readiness (CR) development and to recognize important factors that may influence the diffusion of these technologies in Vietnam.

Surveys on public perception and expert views of CCS have been conducted widely in developed countries because social acceptance is an important factor in spreading this new technology (Edelgard Gruber et al. 2009; Cremer et al. 2009; Shackley et al. 2009; Simon Shackley et al. 2007). Except some studies on the potential for deploying CCS (APEC 2010; Vietsopetro 2004; ADB 2012a; ADB 2012b), there is a lack of similar surveys in Vietnam because CCS is still a new concept. In addition, Vietnam is not drawn to CCS because the country has contributed a minor share of global $\mathrm{CO}_{2}$ emissions and has not yet set any $\mathrm{CO}_{2}$ emission targets for the coming decades. Without a stronger change in climate policy, it is unlikely that Vietnam would sign any binding emission targets in the near future. In this context, the research question is the following: "What would make Vietnam more interested in CCS?" By conducting interviews with researchers, policy makers and industrial energy experts, the authors test the following hypothesis: Vietnam would not be interested in CCS technologies for the next two decades unless climate change policy and the price of $\mathrm{CO}_{2}$ deviate from the expected baseline in the country.

First, this study presents the opinions of the interviewees on barriers to and incentives for CCS development, in terms of technology, economics and policy. Then, the authors present the factors that influence the deployment of CCS in Vietnam. From the expert opinions, the authors find that the hypothesis is true. In the latter section of this paper, the authors discuss solutions to manage the difficulties that are identified in the previous sections of the paper. 


\section{Literature on the experts' views on CCS policy}

Since 2000, several studies based on surveys regarding CCS deployment have been conducted in developed countries, mainly in Europe, the UK, Australia, Japan, the US, and Canada. Most of these studies empirically investigate the public's general awareness of CCS issues and the factors that influence public opinion. Existing studies have shown that the perception of lay people is low in terms of understanding CCS technologies and its relation to climate change (Edelgard Gruber et al. 2009). In 2006, 512 stakeholders in Europe presented their opinions for the first time through a survey regarding the role of CCS in Europe's energy future. The survey captured the opinions of European stakeholders who were classified by professional interests and/or involvement in energy industries and climate policy (Simon Shackley et al. 2007). Seventyfive percent of interviewees in the study expected that between now and 2050, a large deployment of CCS would be definitely or most likely necessary to achieve $\mathrm{CO}_{2}$ emission cuts in their country. Concerning whether CCS development would detract from investment in renewable energy technologies, fifty percent of the interviewees said that CCS should receive incentives at the same or a higher level as renewable energy. The study also noted that the energy industry pays attention to CCS more than environmental NGOs.

The United States (US) has indicated its strong interest in CCS technologies over the last two decades, such as the reduction of $\mathrm{CO}_{2}$ emissions from coalfired power plants. Given uncertainties in technical, economic and environmental aspects, policies to develop CCS are a key factor for the future of this technology. Rumika Chaudhry et al. (2013) have conducted a survey to explore energy policy stakeholders' perceptions of CCS in four geographically and demographically diverse areas: government, industry, academia, and nongovernmental organizations. The aim of the research is to understand and compare the perceptions of CCS among stakeholders who shape state-level energy policy. The differentiation in stakeholder priorities and perceptions found by the study has identified challenges in the deployment of CCS at the national level in the US. According to the study, stakeholders across all areas suggested that CCS deployment will depend on a favourable economic environment coupled with suitable regulatory measures. The socio-political context for CCS is rapidly changing in each of these four areas, and the landscape is also changing at the national and international levels. Policy makers and energy planners at the state level in the US are the main actors who make decisions influencing their states' energy future and the potential for CCS to play a role.

China leads among developing countries that are active in the CCS sector. The country has a scattering of pilot CCS projects, such as a scheme in Inner Mongolia to capture and store 120 thousand tonnes of $\mathrm{CO}_{2}$ per year, a capture 
pilot of 10 thousand tonnes per year in Chongqing. By the end 2014, China has developed 11 large-scale integrated CCS projects which account for 20 percent of the total large-scale CCS projects worldwide (Global CCS Institute 2014). Stakeholder perceptions and acceptance of CCS technologies have also been investigated there. In mid-2008, Liang Dapeng et al. (2009) conducted semistructured interviews with experts to investigate their opinions regarding four crucial aspects that influence CCS in China. From 2006-2012, Xi Liang et al (2013) conducted a major survey of Chinese stakeholders-to assess the potential challenges of and opportunities for CCS projects. According to the surveys, climate change is a priority for all stakeholders. Notably, the expectation of international financial support for China to implement CCS demonstration projects has gradually decreased.

Although many studies investigating the opinions of CCS stakeholders have been conducted worldwide, there is a lack of such studies in Vietnam where CCS would have considerable room to develop. Total $\mathrm{CO}_{2}$ emissions in Vietnam will increase from 178 million tons in 2010 to 830 million tons by the end of 2030 (Nguyen Anh Tuan 2011). Given that Vietnam is one of the few

Southeast Asian countries that possess considerable potential for $\mathrm{CO}_{2}$ storage capacity (ADB 2012a), significant development of CCS technologies could reduce its $\mathrm{CO}_{2}$ emissions. Under the specific socio-economic conditions of Vietnam, interviews regarding the deployment of CCS would provide different points of view that would be useful to promote the technology in Vietnam. The authors have conducted such interviews, whose details and results are presented in the next sections of this paper.

\section{Description of interview method and themes}

We conducted interviews with 16 stakeholders/experts who have interests and/or are involved in CCS issues at a level pre-assessed by the authors through the stakeholders' academic/working profiles. The interviewees are working for the central government, energy industry or scientific research institutes with either direct or indirect involvement in the energy development and the environmental assessment of Vietnam, including energy planners, energy policy makers, electricity market operators, energy-environmental experts, energy economic researchers and thermal energy operators. Some of them have worked on initial studies regarding CCS issues in Vietnam (APEC 2010; APEC 2005; ADB 2012b). All of the organizations that we have worked with are shown in Table 1 of the Annex.

We obtained our interview method from the book of Anne Gotman (2005). The main discussion points of the interview were sent to the experts at least 5 days in advance to ensure that they had time to prepare as well as decide the most convenient time and place for the interview. Most of the stakeholders preferred 
to discuss the CCS issues at their office. Some experts left their offices for the interview because they thought political issues were too sensitive to discuss there. With one exception of Ho Chi Minh City, the interviews were conducted in Hanoi, which is the most important city for energy research and policy making in Vietnam. Table 1 presents more information about the interviewees.

CCS technologies' maturity then their commercial availability would be expected to be after 2020 in developed countries and few years later in developing countries as Vietnam (Sweeney 2012; ZEP 2007; International Energy Agency 2009). Official energy development plans of Vietnam have just examined the energy system for a period of the next two decades. In addition, if the time boundary of the questions is too far from the present, interviewees would have more difficulties to respond. Therefore, at the beginning of the interviews, we always state that the time boundary of all questions is two decades to come.

Table 1: Profiles of the experts interviewed

\begin{tabular}{|c|c|c|c|c|c|}
\hline \multicolumn{2}{|c|}{ Gender } & \multicolumn{2}{|c|}{ Academic level } & \multicolumn{2}{|c|}{ Scientific expertise } \\
\hline Male & $25 \%$ & Bachelor & $25 \%$ & Environment & $6 \%$ \\
\hline \multirow[t]{3}{*}{ Female } & $75 \%$ & Master & $50 \%$ & Engineering & $68 \%$ \\
\hline & & $\mathrm{PhD}$ & $25 \%$ & Economics & $13 \%$ \\
\hline & & & & Others & $13 \%$ \\
\hline
\end{tabular}

The content of the interview is divided into the following three themes: the necessity of CCS/CR deployment in Vietnam, main obstacles to the development of CCS in Vietnam and solutions that the country could apply to address the obstacles identified. The first theme is designed to determine the role of CCS in Vietnam's climate change policy in general and its strategy to reduce $\mathrm{CO}_{2}$ emissions in particular. The second theme identifies the most likely technical, economic and financial obstacles to the development of CCS in Vietnam. The final theme suggests the most influential factors, incentives and solutions to solve the obstacles identified earlier. Those outcomes could assist policy-makers in designing suitable strategies to promote CCS technologies to reduce $\mathrm{CO}_{2}$ emissions. Details of the three themes are presented in Table 2 of the Annex.

\section{CCS is potentially relevant}

As shown in Table 2, the relevance of CCS technologies to the low carbon development in Vietnam is considerably high. Experts suppose that CCS would have a number of advantages to develop, especially in the fossil-fuel-based industries, in Vietnam.

CCS: an efficient strategy for climate change mitigation 
All of the interviewees agree that CCS could be an efficient mitigation strategy for worldwide climate change in general and for Vietnam in particular. "The primary reason is that the consumption of coal and other fossil fuels in Vietnam will increase rapidly in the next decades, especially in the power sector", commented an expert. The second reason is that CCS technologies could be integrated either in the current energy sector by retrofitting fossil fuel-based power plants or in future power plants at the beginning of their design and construction. However, the experts doubt how CCS technologies can compete with other alternatives for reducing $\mathrm{CO}_{2}$ emissions, such as renewable energy and energy efficiency under time and financial constraints.

Table 2: Relevance of CCS technologies to the low carbon development in Vietnam ${ }^{1}$

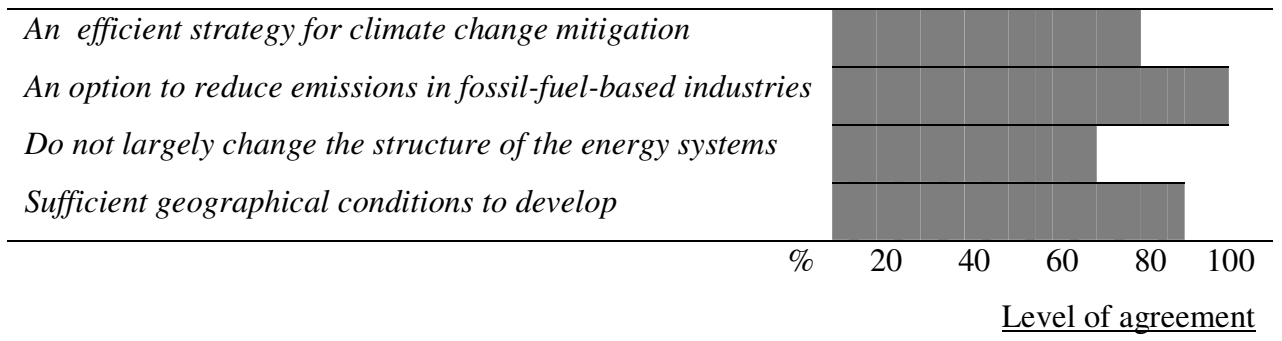

CCS: a good option to reduce emissions in fossil-fuel-based industries

All of the experts believe that the rapid economic growth in Vietnam in the next decades could lead to a considerable expansion of fossil fuel use. According to experts at the Ministry of Industry and Trade, the coal industry in 2010 accounts for approximately 35 percent of the total primary energy use in Vietnam, and coal-fired power capacity is more than 20 percent of the total power capacity. In the same year, coal use for power generation accounted for approximately 36 percent of the total coal consumption in the country (Institute of Energy 2011), (General Statistics Office of Vietnam 2011), (Khanh Toan, Minh Bao, and Ha Dieu 2011). With the current plan for power development in Vietnam, coal-fired power plants will dominate the energy sector with the largest share of 66 percent in the total power capacity by 2030 in the high demand scenario, as stated by a researcher at the Institute of Energy (Electricity of Vietnam 2014). This Institute has implemented the national energy development plans in Vietnam for more than 30 years. The expert concluded: "With such a high share of coal power in the power system, the country, therefore, has to implement modern technologies to reduce $\mathrm{CO}_{2}$ emissions from the combustion of coal in the power sector".

\footnotetext{
${ }^{1}$ Most of interviewees explained their agreement levels verbally but few interviewees did numerically. Except 2 interviewees who did not answer the question about "to change the structure of the energy systems", all other interviewees answered all questions
} 
One advantage of CCS technologies compared with other low carbon technologies is that the country does not need to change the structure of its energy sector in the future. Empirical evidence shows that it is possible to integrate CCS technologies in coal power plants without modifying the main process of electricity generation (IEA 2012; Global CCS Institute 2013b; MIT Energy Initiative 2009; Chalmers, H. 2009). This integration could be implemented by either retrofitting existing power plants or adding this technology to the design of new coal power plants. Twelve experts concluded that if Vietnam cannot avoid burning coal to fuel its economy, CCS technologies could be important to reduce $\mathrm{CO}_{2}$ emissions required by stronger climate policies, which would be compulsory for developing countries such as Vietnam.

Along with its considerable potential in the power sector, CCS could also be implemented efficiently in other industries, for example, the oil industry. Five experts who work closely with the oil industry in Vietnam supposed that the White Tiger CCS project in enhanced oil recovery (EOR) (Vietsopetro 2004) could be a beginning for further development of CCS in the oil and gas industries. The EOR project also shows that there is a need for applying CCS technologies in the country. Without CDM credits as expected, the project is still under operation with internal benefits from oil recovery.

\section{Obstacles to CCS/CR deployment in Vietnam}

Despite CCS's advantages, Vietnam could face several obstacles if the country uses this technology to reduce $\mathrm{CO}_{2}$ emissions in the coming decades. According to the experts' opinions, those obstacles concern the following: technology, environment, energy security, finance, and policy. These issues are presented in greater detail in the following sections.

\section{Potential risk events}

Although there is no evidence of accidents from CCS projects, several experts are still concerned regarding the technical risks of the construction and operation of these projects. Most experts are familiar with technologies to implement CCS projects, but the combination of these technologies is still a new concept to the public. Little experience has been accumulated in Vietnam because only one CCS project has been implemented in the country: the White Tiger EOR CCS project. The main purpose of this project is the recovery of more oil, rather than collecting and injecting $\mathrm{CO}_{2}$ into the oil field. Notably, one expert who works for the General Department for Energy said that "The purpose to increasing $8 \%$ of oil production of this CCS project was not achieved during its operation. The oil production has decreased after integrating the CCS facilities". This reduction may be caused by the dissolution of gases and oil during the process of injecting $\mathrm{CO}_{2}$ into the oil field. Then, 
experts are concerned regarding accidents or unexpected events that could occur in power plants or storage sites during the long lifetime of CCS projects. An expert at MOIT emphasized that "Vietnam is highly affected by natural disasters such as hurricanes, floods and earthquakes. This point should be seriously considered when implementing any CCS project in the country and to foresee the technical risks".

Leakage of stored $\mathrm{CO}_{2}$, both onshore and offshore, is a potential environmental risk (Blackford et al. 2013; Pearce et al. 2014; Smith et al. 2013; Steven, Smith, and Colls 2010). Eight of the sixteen experts interviewed suppose that large-scale $\mathrm{CO}_{2}$ storage would negatively affect geological systems, such as underground water or faults in the rock layers, as well as marine ecosystems in the case of offshore storage. In addition, CCS construction from $\mathrm{CO}_{2}$ emitting sources to the storage could damage local environments. However, two experts who participated in studies on CCS's potential in Vietnam and other Southeast Asian countries said that "the risk of $\mathrm{CO}_{2}$ leakage is not very important because both international and national experiences in the natural gas industry have shown that Vietnam can operate and manage technologies to transport and store gases safely".

\section{Additional energy consumption for CCS}

Additional energy consumption for CCS in power plants is a concern for the experts. Experts, whose work is related to Vietnam's energy development plans and the operation of coal-fired power plants, noted that the processes to capture, transport and inject $\mathrm{CO}_{2}$ would consume a considerable amount of energy. This increase of fuel consumption will lower the efficiency of fossil fuel-based power plants (Rubin, Chen, and Rao 2007). In other words, a power plant that integrates CCS technologies needs more fuel to generate the same amount of electricity compared with a similar plant without CCS technologies. If CCS technologies are implemented on a large scale, Vietnam would need to burn more fossil resources to fuel its economy. Despite the decreased amount of $\mathrm{CO}_{2}$ released into the atmosphere, the country would be under pressure to increase either the production capacity of domestic coal or coal imports while applying CCS technologies. Both options would increase the concern of energy balance in the country. In the most optimistic scenario where financial credits gained due to the reduction of $\mathrm{CO}_{2}$ emission, CCS technologies could help coal power plants reduce their total generation costs. As a result, this reduction would make electricity from coal more competitive than electricity from renewable resources. Then, CCS technologies could face objections from renewable energy supporters.

Financial risks

During the interviews, the experts spent most of the time discussing financial 
and political risks. One expert at MOIT confirmed that: "There is no room for CCS-Readiness in the short-term because under the current regulations of the energy sector of Vietnam, investment costs of CCS-Readiness in power plants are not taken into the depreciation period and then not into the cost of electricity generation". Integrating CCS/CCS-Readiness facilities would make the total investment cost of a power plant increase up to ten percent ( $\mathrm{Jia} \mathrm{Li}$ 2011; Mark C. Bohm 2013; Liang and Reiner 2013; International Energy Agency 2007; Li, Liang, and Cockerill 2011). Power plant operators would not be interested in CCS-Readiness if the corresponding investment is not included in the electricity costs and before the operators obtain benefits from $\mathrm{CO}_{2}$ reductions after the full integration of CCS technologies. To cover the costs of CCS technologies and the additional fuel consumption to run the CCS systems, the power plant operators can expect only the revenue from selling the credits of their $\mathrm{CO}_{2}$ emission reductions. This revenue would depend on not only the reduction, which they can technically control, but also the market price of $\mathrm{CO}_{2}$.

\section{Solutions to advance CCS in Vietnam}

Along with discussing potential risks that may prevent the development of CCS in Vietnam, the experts also suggest how to eliminate those risks. Their suggestions could be grouped as follows: issue more relevant policies, raise awareness of CCS, carry out more studies, and promote demonstration/pilot projects. The obstacles to the development of CCS/CR technology in Vietnam and suggested solutions are summarised in Table 3.

Table 3: Obstacles and solutions to CCS/CR deployment outlined by the CCS experts

\begin{tabular}{ll}
\hline Obstacles & Solutions \\
\hline Accidents & Issue more environment and safety standards \\
& Implement CCS pilot projects and evaluate their impacts \\
$\begin{array}{l}\text { Additional energy } \\
\text { consumption for CCS }\end{array}$ & Implement more energy efficiency measures \\
$\begin{array}{l}\text { Lack of appropriate } \\
\text { policies }\end{array}$ & Develop more renewable energy sources \\
& $\begin{array}{l}\text { Conduct more scientific and practical studies on CCS issues in } \\
\text { Vietnam }\end{array}$ \\
& Improve knowledge and awareness of CCS for the stakeholders \\
High costs & Government's supports: direct financial supports, taxes, etc. \\
& Financial benefits from selling credits of CO ${ }_{2}$ reductions \\
& International financial supports \\
Financial risks & Open framework/flat-form for carbon monitoring and trading in \\
& Vietnam
\end{tabular}

Sound and long-term regulations and policies 
All experts agreed that policies to promote CCS are necessary to develop this technology in Vietnam. Even an expert from the academic sector emphasized: "Policy is definitely the most important initial factor for Vietnam to bring CCS technologies in the country". Four experts said that Vietnam, to promote and manage CCS projects, should establish a special board operated under the following three ministries: Ministry of Industry and Trade, Ministry of Environment and Natural Resources, and Ministry of Science and Technology. According to twelve experts, policies regarding financial matters should be issued. Integrating CCS technologies in the power sector should be given, at the least, the same incentives as other clean electricity generation technologies, such as technology imports, taxes, loan interest, and land use rights. In addition, the investment of capture readiness in new power plants should be depreciated in the same way as other investment costs and included in the cost of electricity generation before CCS technologies are integrated. However, the experts also worry that these policies cannot be achieved because of the current lack of investment in the power sector and the availability of other technologies that generate cleaner electricity and have more acceptable investments.

\section{Energy and environment standards}

To address environmental issues, standards for environmental protection and clear risk management at $\mathrm{CO}_{2}$ production sources, storage sites and on transportation systems should be designed by stakeholders and approved by the government of Vietnam. In fact, some regulations require the control of other types of air pollutants, such as $\mathrm{CO}_{2}$ and $\mathrm{NOx}$, such as coal-fired power plants with static electric air controllers. Three experts said that more regulations for $\mathrm{CO}_{2}$ emissions are needed when the country starts developing CCS projects.

Regarding energy security, two experts stated that a clear energy development strategy should be first clarified to lead the power sector in decades to come. If high-intensity $\mathrm{CO}_{2}$ power plants continue to play a role in the system, standards for $\mathrm{CO}_{2}$ emissions and technologies to reduce these emissions should be stated clearly in the strategy. In addition, an expert from the energy industry says standards for more power efficiency in power plants could reduce the additional energy consumption of the CCS infrastructure.

\section{Evaluate the impacts of CCS projects}

Because there are insufficient studies regarding CCS potential in Vietnam, most experts agree that more studies are necessary. These studies should not only examine Vietnam's potential for $\mathrm{CO}_{2}$ storage capacity but also analyze its technical and economic aspects. In addition, these studies should consider external costs and assess the environmental and social impacts of CCS projects at the local level to calculate the full cost of this technology. Five experts said that scenarios to respond to accidents, such as leakages or interactions with 
water, heavy metals, particulates and acid gases that may occur during the transportation and storage of $\mathrm{CO}_{2}$, should be developed to demonstrate the safety of CCS projects. A scientific mechanism to control and monitor the CCS project should be implemented to avoid unsafe operation. One example is the current operation of the hydro-power system in the central part of Vietnam. An expert at MOIT said that the White Tiger CCS project is intended to store approximately 7.4 million tons of $\mathrm{CO}_{2}$ per year and to increase the production of the White Tiger oil field additionally 8 percent. However, the operation of the project has not met the expected outcomes. Oil production has actually decreased resulting from interactions between $\mathrm{CO}_{2}$ and chemical elements in the oil field.

\section{Improve knowledge and awareness of CCS for the stakeholders}

Having sufficient studies on CCS technologies in Vietnam could improve the perception of stakeholders, such as financial investors, fossil fuel-based power operators, and policy makers, who play crucial roles in developing CCS projects. Two experts who teach energy systems said that introducing seminars of CCS technologies in the relevant training programs, such as the Electricity Faculty at the Hanoi University of Technology or the Energy Faculty at the Electric Power University, could not only increase the awareness of CCS but also prepare human resources for this technology in the future. Fundamental information on CCS technologies should be spread to the public through the media in concrete and understandable ways.

\section{International financial supports for demonstrative projects}

Most experts considered demonstrative projects the first step to develop CCS technologies in Vietnam. An expert at EVN said that: "As in other new technologies in the power sector in Vietnam, a demonstration of investment from the private sector or international support is the easiest path to promote CCS in Vietnam". These projects would provide more precise data and convey good indicators to potential investors to further develop CCS projects. The success of the demonstrative projects would strongly influence the perception of policy-makers and the acceptance of the public toward CCS technologies. Afterwards, policy makers could enact more legal frameworks on and incentives for future CCS projects. Most experts from industry agree that to develop a demonstrative project, the government should play a leading role to avoid unexpected risks to pioneers. Private investors would invest in commercial projects after policies for CCS are clear. Conversely, experts from the ministries and research institutes presume that international organizations or private investors should invest in the demonstrative projects. If the government can conduct good feasibility studies, it should give initial incentives to implement demonstrative projects. This contrary opinion requires 
a rational solution to initiate a CCS demonstrative project in Vietnam.

CCS: not first but must-be-considered option which should be supported by the Government

Although there are many advantages of CCS technologies, all 16 experts think CCS should not be the first choice for $\mathrm{CO}_{2}$ emission reductions. An expert from the energy industry said: "Vietnam could take advantage of its various renewable energy sources to meet its power demand as well as reduce $\mathrm{CO}_{2}$ emissions rather than burn coal then apply expensive technology such as $C C S^{\prime \prime}$. The experts thought that other technologies such as renewable energy will significantly reduce $\mathrm{CO}_{2}$ emissions. They therefore agreed that CCS technologies should reinforce renewable energy rather than replace it. Interestingly, 10 experts agree that CCS should be combined with clean coal technology. Furthermore, the integrated gasification combined cycle into the CCS model is seen as the best technology for the future. In considering risks, experts contend that the technological and operational risks are not serious because sufficient knowledge and technology exists to monitor, mitigate and control these risks in $\mathrm{CO}_{2}$ capture, transportation, injection and storage. Vietnam's energy system and environment are so fragile that CCS technologies must be implemented only if it can be proved safe. In general, experts believe that there are still too many risks to the environment and the energy system that prevent CCS development on a commercial scale. Government should also play a key role in funding and policy making. In the short term, financial incentives are the main approach for investment in CCS technologies. In the long term, however, a sound business environment that is characterized by mature technology, market-oriented mechanisms for price, and a complete legal system should be established.

\section{Discussion}

The lack of policy: the main restriction on CCS development in Vietnam Analyzing responses of the interviewees, the authors conclude that the lack of policy is the main restriction on CCS development in Vietnam. Because of insignificant pressure from carbon emission taxes, businesses in Vietnam have no incentive to reduce their $\mathrm{CO}_{2}$ emissions. If emission taxes are established, companies will balance between paying these taxes and investing in emission reduction. Therefore, an emission quota or proper emission taxes must be set by the government. In addition to quota standards and carbon taxes, policies in the electricity market could be established.

High cost and risks: Challenges for the commercial development of CCS

According to the interviews, the government is not optimistic regarding CCS technologies, and the scientific institutes have no in-depth research on it, which 
led to little attention to CCS from the industrial sector. Developing a market for CCS, through the creation of commercial conditions, could result in reducing commercial risks. In such conditions, more investors would be interested in CCS. Currently, two of the biggest challenges for the commercial development of CCS are the costs and the risks. Thus, according to the interviews, opening the carbon trading scheme, at national level, can enhance the confidence for CCS investment and guarantee stable profits of enterprises involved in CCS activities. Vietnam could take lessons learnt from the emission trading systems which have been implemented Kazakhstan and South Korea along with the pilot experiences launched in China and Japan (Isl et al. 2015; infrastructurene.ws 2013) to develop its own scheme in the future. Apart from the technology and cost, the main factor influencing CCS market development is Vietnam's scant attention to $\mathrm{CO}_{2}$ commercial values, such as EOR, which causes the devaluation of all CCS projects. In addition, the insufficiency of data for qualified storage sites decrease CCS's commercial potential, and $\mathrm{CO}_{2}$ capture enterprises may suspect that the CCS business cannot be guaranteed over a long period of time. Meanwhile, because there is no clear division of responsibilities and duties, it is difficult to determine who is responsible for byproducts, such as $\mathrm{CO}_{2}$. Accordingly, no enterprises are willing to accept the risks of managing a CCS business.

\section{EVN: the biggest influential stakeholder for CCS development in Vietnam}

In Jan 1995, the state-owned national power company, Electricity of Vietnam (EVN), was created, which completely controls power generation, transmission, distribution and sales. Additionally, the company controls nearly all of the power grids and two-thirds of the power plants in Vietnam. However, the company's high market power and a low level of innovation for new technologies reduce its driving force. The company directs less attention to renewable energy and CCS technologies than coal- and gas-fired technology (Institute of Energy 2011). In the energy sector, enterprises other than EVN are willing to adopt new technologies as long as they can be competitive and profitable. Strongly influencing policy-makers and industry, EVN is the most powerful company in Vietnam's power sector. If CCS was promoted by EVN, the technology would have a greater influence on the country.

\section{Commitment to cut $\mathrm{CO}_{2}$ emission down in Vietnam}

The recent global economic crisis has caused more difficulties for CCS projects worldwide. Other more immediate development priorities (such as food security, emergency relief, health and education) often overshadow climate change projects. The larger the funding amount being sought (like CCS projects), the greater competition it will face with other aid priorities (Global CCS Institute 2013a). Mainly developed countries that are under an obligation 
to reduce their $\mathrm{CO}_{2}$ emissions continue CCS projects. By the end of 2014, the largest share of large-scale CCS projects ${ }^{2}$ are deployed in the United States, Europe and Canada, up to 38 over 55 projects globally. In addition, almost all current CCS projects worldwide are directly or indirectly invested or funded by developed countries who have official commitments to reduce its emissions (Global CCS Institute 2014). In contrast, developing countries such as Vietnam do not give priority to the technology partly because of their difficulty in financing other development projects, such as in the power sector. Only financial support and stronger international agreements on technology transfer can initiate the CCS industry in developing countries. In the case of Vietnam, the authors find that fossil fuel industries must take more responsibility for their $\mathrm{CO}_{2}$ emissions, and then they could pay more attention to $\mathrm{CCS}$ technologies.

\section{Conclusions}

Based on interviews conducted in 2013, this article summarizes and analyzes the opinions of experts regarding barriers to and incentives for CCS deployment in Vietnam. This paper demonstrates that attitudes of the Vietnamese government, scientific institutions and the industry toward CCS is not optimistic as a result of the low priority for $\mathrm{CO}_{2}$ reductions, investment restrictions, the lack of an appropriate regulation system, and uncertainties, i.e. risks of high costs and leaks, and efficiency of CCS. Any future incentives, such as financial supports, laws and the venture capital market, would require widespread participation from stakeholders in government and industry. Yet we found that at this stage, experts at research institutes, rather than experts in government or industry, had paid more attention to CCS. Our respondents did not frame developing CCS as a problem to be solved.

The most frequently cited necessary conditions to change this situation were, unsurprisingly, a rapid improvement of $\mathrm{CO}_{2}$ capture technology, reducing costs and improving risk management. More knowledge of CCS, which a demonstration project could provide, is required to attract the attention of government and industry.

Some experts said that an important objective of climate policy in Vietnam should be the effective use of $\mathrm{CO}_{2}$ emitted from fossil fuel based power plants rather than only store it as a polluting waste. Promoting the use of $\mathrm{CO}_{2}$ for specific purposes, such as EOR, would stimulate demand and develop value for

\footnotetext{
${ }^{2}$ Large-scale integrated CCS projects (LSIPs) are defined as projects involving the capture, transport, and storage of $\mathrm{CO}_{2}$ at a scale of: at least 800,000 tonnes of $\mathrm{CO}_{2}$ annually for a coalbased power plant, or at least 400,000 tonnes of $\mathrm{CO}_{2}$ annually for other emissions-intensive industrial facilities (including natural gas-based power generation).
} 
CCS.

Another pre-requisite to the development of CCS in the power sector mentioned by the experts was an electricity tariff reform, which internalizes the costs of carbon emissions. Experts all considered that carbon taxes and the establishment of an emission trading market was the foundation for building a system to manage CCS technologies. Improving the transmission network to reduce the losses and costs was cited as an important step to allow the development of all new green electricity technologies. Initially, financial incentives from the government were expected to play an important role.

Based on these reasons, our study concludes that Vietnam would not be interested in CCS technologies for the next two decades unless climate change policy and the price of $\mathrm{CO}_{2}$ deviate from the expected baseline. If and when those changes are enacted, to prepare the market for deploying CCS a framework of regulations and standards which allow a sound business model will be expected.

\section{References}

ADB. 2012a. Prospect for Carbon Capture and Storage In Southeast Asia. http://www.adb.org/publications/prospects-carbon-capture-and-storage-southeast-asia.

2012b. Road Map for Carbon Capture and Storage Demonstration and Deployment. http://www.adb.org/projects/46052-001/details.

Alain Blanchet and Anne Gotman, 2005. L'entretien: L'enquête et ses méthodes, Armand Colin. ISBN: 2200342349

APEC. 2005. CO2 Storage Prospectivity of Selected Sedimentary Basins in the Region of China and South East Asia. http://www.globalccsinstitute.com/publications/co2storage-prospectivity-selected-sedimentary-basins-region-china-and-south-east-asia.

2010. Assessment of the CCS Potential of CO2 Co-Produced with Natural Gas in South East Asia. http://www.globalccsinstitute.com/publications/assessment-captureand-storage-potential-co2-co-produced-natural-gas-south-east-asia.

Blackford, J., C. Hattam, S. Widdicombe, N. Burnside, M. Naylor, K. Kirk, P. Maul, and I. Wright. 2013. "7 - CO2 Leakage from Geological Storage Facilities: Environmental, Societal and Economic Impacts, Monitoring and Research Strategies." In Geological Storage of Carbon Dioxide (co2), edited by Jon Gluyas and Simon Mathias, 149-78. Woodhead Publishing. http://www.sciencedirect.com/science/article/pii/B9780857094278500071.

Chalmers, H. 2009. "Retrofitting CO2 Capture to Existing Power Plants as a Fast Track Mitigation Strategy." presented at the ASME 3rd International Conference on Energy Sustainability.

Cremer, C. et al., 2009. Stakeholder acceptance of carbon capture and storage in Germany. Energy Procedia, 1(1), pp.4783-4787. http://dx.doi.org/10.1016/j.egypro.2009.02.304

Edelgard Gruber et al. 2009. Professional and Public Acceptance for Carbon Capture and Storage Activities. Fraunhofer Institute for Systems and Innovation Research, Karlsruhe. http://www.isi.fraunhofer.de/isi-media/docs/isi-publ/2009/ISI-A-4-09.pdf. 
Electricity of Vietnam. 2014. Database of the electricity system of Vietnam. Hanoi: Electricity of Vietnam.

General Statistics Office of Vietnam. 2011. Statistics Yearbook of Vietnam 2011. Hanoi: General Statistics Office of http://www.gso.gov.vn/default_en.aspx?tabid=515\&idmid=5\&ItemID=12576.

Global CCS Institute. 2013a. Making the Case for Funding Carbon Capture and Storage in Developing Countries. Global CCS Institute. http://www.globalccsinstitute.com/publications/making-case-funding-carbon-captureand-storage-developing-countries.

2013b. "What to Do with Existing Coal-Fired Electricity Generation Plants." November.

http://www.globalccsinstitute.com/insights/authors/davidhanly/2013/11/08/what-do-

existing-coal-fired-electricity-generation-plants.

2014. The Global Status of CCS 2014. Global CCS Institute. http://www.globalccsinstitute.com/publications/global-status-ccs-2014.

IEA. 2012. CCS Retrofit: Analysis of the Globally Installed Coal-Fired Power Plant Fleet. International Energy Agency. http://www.iea.org/publications/freepublications/publication/ccs-retrofit-analysis-ofthe-global-installed-power-plant-fleet.html.

infrastructurene.ws. 2013. "New Carbon Trading Markets Will Be Opening Worldwide I Infrastructure News." http://www.infrastructurene.ws/2013/07/24/new-carbon-tradingmarkets-opening-worldwide/.

Institute of Energy. 2011. The 7th Power Development Plan. Hanoi: Institute of Energy.

International Energy Agency. 2007. CO2 Capture Ready Plants.

- 2009. Ensuring Green Growth in a Time of Economic Crisis: The Role of Energy Technology. International Energy Agency. https://www.iea.org/publications/freepublications/publication/ensuring_green_growth. pdf.

Isl, International Center for Climate Governance, of San Giorgio Maggiore 8 I.-30124 Venice, Italy This website is under constant update For questions, and Comments or Suggestions. 2015. "South Korea Launches Its Carbon Market." Climate Policy Observer. Accessed March 5. http://climateobserver.org/south-korea-launches-carbonmarket/.

Jia Li. 2011. "Financing New Power Plants 'CCS Ready' in China - a Case Study of Shenzhen City,." Energy Procedia.

Khanh Toan, Pham, Nguyen Minh Bao, and Nguyen Ha Dieu. 2011. "Energy Supply, Demand, and Policy in Viet Nam, with Future Projections." Energy Policy, Asian Energy Security, 39 (11): 6814-26. doi:10.1016/j.enpol.2010.03.021.

Liang Dapeng and Wu Weiwei, 2009. Barriers and incentives of CCS deployment in China: Results from semi-structured interviews. Energy Policy, 37(6), pp.2421-2432. DOI: 10.1016/j.enpol.2009.02.032

Liang, Xi, and David Reiner. 2013. "How China Can Kick-Start Carbon Capture and Storage." https://www.chinadialogue.net/article/show/single/en/6047-How-China-can-kick-startcarbon-capture-and-storage.

Li, Jia, Xi Liang, and Tim Cockerill. 2011. "Getting Ready for Carbon Capture and Storage through a 'CCS (Carbon Capture and Storage) Ready Hub': A Case Study of Shenzhen City in Guangdong Province, China." Energy 36 (10): 5916-24. 
doi:10.1016/j.energy.2011.08.030.

Mark C. Bohm. 2013. Capture-Ready Coal plants-Options, Technologies and Economics. Accessed May 22. http://www.citeulike.org/user/banderso/article/3143385.

MIT Energy Initiative. 2009. Retrofitting of Coal-Fired Power Plants for CO2 Emissions Reductions. Massachusetts Institute of Technology. http://mitei.mit.edu/publications/reports-studies/retrofitting-coal-fired-power-plantsco2-emissions-reductions.

Nguyen Anh Tuan, 2011. Carbon Capture and Storage in Vietnam. 6th Asian Clean Energy Forum, Manila 2011. Available at: http://fr.slideshare.net/globalccs/ccs-in-vietnamnnguyen-anh-tuan [Accessed September 9, 2013].

Pearce, Jonathan, Dave Jones, Jerry Blackford, Stanley Beaubien, Edwin Foekema, Vassiliki Gemeni, Karen Kirk, et al. 2014. "A Guide for Assessing the Potential Impacts on Ecosystems of Leakage from CO2 Storage Sites." Energy Procedia, 12th International Conference on Greenhouse Gas Control Technologies, GHGT-12, 63: 3242-52. doi:10.1016/j.egypro.2014.11.351.

Rubin, Edward S., Chao Chen, and Anand B. Rao. 2007. "Cost and Performance of Fossil Fuel Power Plants with CO2 Capture and Storage." Energy Policy 35 (9): 4444-54. doi:10.1016/j.enpol.2007.03.009.

Rumika Chaudhry, Miriam Fischlein, Joel Larson, Damon M. Hall, Tarla Rai Peterson, Elizabeth J. Wilson, Jennie C. Stephens, 2013. Policy stakeholders' perceptions of carbon capture and storage (CCS): a comparison of four U.S. states. Journal of Cleaner Production, 52, pp.1-12. http://dx.doi.org/10.1016/j.jclepro.2013.02.002

Simon Shackley, David Reiner, Paul Upham, Heleen de Coninck, Gudmundur Sigurthorsson, Jason Anderson, 2009. The acceptability of CO2 capture and storage (CCS) in Europe: An assessment of the key determining factors: Part 2. The social acceptability of CCS and the wider impacts and repercussions of its implementation. International Journal of Greenhouse Gas Control, 3(3), pp.344-356.

Simon Shackley, Holly Waterman, Per Godfroij, David Reiner, Jason Anderson, Kathy Draxlbauer, Todd Flach, 2007. Stakeholder perceptions of CO2 capture and storage in Europe: Results from a survey. Energy Policy, (35), pp.5091-5108.

Smith, K. L., M. D. Steven, D. G. Jones, J. M. West, P. Coombs, K. A. Green, T. S. Barlow, et al. 2013. "Environmental Impacts of CO2 Leakage: Recent Results from the ASGARD Facility, UK." Energy Procedia, GHGT-11, 37: 791-99. doi:10.1016/j.egypro.2013.05.169.

Steven, M. D., K. L. Smith, and J. J. Colls. 2010. "12 - Environmental Risks and Impacts of Carbon Dioxide (CO2) Leakage in Terrestrial Ecosystems." In Developments and Innovation in Carbon Dioxide (Co2) Capture and Storage Technology, edited by M. Mercedes Maroto-Valer, 2:324-43. Woodhead Publishing Series in Energy. Woodhead Publishing. http://www.sciencedirect.com/science/article/pii/B9781845697976500126.

Sweeney, Graeme. 2012. "Post 2020, CCS Will Be Cost-Competitive with Other Low-Carbon Energy Technologies." Greenhouse Gases: Science and Technology 2 (1): 6-8. doi:10.1002/ghg.1276.

Vietsopetro. 2004. The White Tiger Oil Field Carbon Capture and Storage (CCS) Project in Vietnam: Project Design Document. http://cdm.unfccc.int/methodologies/PAmethodologies/pnm/byref/NM0167.

Xi Liang and David Reiner, 2013. The Evolution of Stakeholder Perceptions of Deploying CCS Technologies in China: Survey Results from Three Stakeholder Consultations in 
2006, 2009 and 2012. Energy Procedia, 37, pp.7361-7368.

ZEP. 2007. The Key to Making CO2 Capture and Storage (CCS) Commercially Viable by 2020. the European Technology Platform for Zero Emission Fossil Fuel Power Plants. http://www.zero-

emissionplatform.eu/website/docs/ETP\%20ZEP/EU\%20Flagship\%20Programme\%20 for\%20CCS.pdf. 


\section{Annex}

Table 4: The organizations of experts and their functions

\begin{tabular}{|c|c|c|c|}
\hline Sector & Organization & Function & No. of expert \\
\hline \multirow{4}{*}{ Government } & $\begin{array}{l}\text { Ministry of Industry and Trade } \\
\text { (MOIT) }\end{array}$ & $\begin{array}{l}\text { Energy policy and project investment for } \\
\text { CCS in the national energy development }\end{array}$ & 2 \\
\hline & $\begin{array}{l}\text { Ministry of Environmental and } \\
\text { Natural resources (MONRE) }\end{array}$ & $\begin{array}{l}\text { Environmental and natural resources } \\
\text { protection and management }\end{array}$ & 1 \\
\hline & $\begin{array}{l}\text { Electricity Regulatory } \\
\text { Authority of Vietnam (ERAV) }\end{array}$ & $\begin{array}{l}\text { Issuing regulations for the power system } \\
\text { operation in Vietnam }\end{array}$ & 1 \\
\hline & $\begin{array}{l}\text { Ministry of Science and } \\
\text { Technology (MOST) }\end{array}$ & $\begin{array}{l}\text { Scientific policy and research investment for } \\
\text { the new technologies }\end{array}$ & 2 \\
\hline \multirow{4}{*}{$\begin{array}{l}\text { Industrial } \\
\text { sectors }\end{array}$} & Electricity of Vietnam (EVN) & $\begin{array}{l}\text { Invest in and regulate the largest share of the } \\
\text { power generation sector, all transmission and } \\
\text { distribution systems }\end{array}$ & 2 \\
\hline & $\begin{array}{l}\text { National Load Dispatch Center } \\
\text { (NLDC - AO) }\end{array}$ & $\begin{array}{l}\text { Dispatch the whole power generation and } \\
\text { transmission systems }\end{array}$ & 1 \\
\hline & Coal power plants & Investing in or operating coal power plants & 1 \\
\hline & Energy consultants & Providing energy consulting services & 2 \\
\hline \multirow{3}{*}{$\begin{array}{l}\text { Scientific } \\
\text { institutes }\end{array}$} & Institute of Energy (IE) & $\begin{array}{l}\text { Research on CCS potential and deployment } \\
\text { in Vietnam }\end{array}$ & 2 \\
\hline & $\begin{array}{l}\text { Institute of Energy Science } \\
\text { (IES) }\end{array}$ & $\begin{array}{l}\text { Research on new and clean energy } \\
\text { technologies, implement renewable energy } \\
\text { projects }\end{array}$ & 1 \\
\hline & $\begin{array}{l}\text { Electric Power University } \\
\text { (EPU) }\end{array}$ & Research on electric power systems & 1 \\
\hline
\end{tabular}

Table 5: Interview themes

\begin{tabular}{|c|c|c|}
\hline Theme & Key points & Objectives \\
\hline \multirow{3}{*}{$\begin{array}{l}\text { Necessity of CCS \& } \\
\text { Capture-Readiness (CR) } \\
\text { in Vietnam }\end{array}$} & $\begin{array}{l}\text { Is it a necessary technology in Vietnam for } \\
\text { mitigating climate change }\end{array}$ & \multirow{3}{*}{$\begin{array}{l}\text { To examine advantages and } \\
\text { position of CCS/CR in } \\
\text { Vietnam' energy development } \\
\text { strategy }\end{array}$} \\
\hline & $\begin{array}{l}\text { Is it possible to deploy CCS/CR in Vietnam } \\
\text { now }\end{array}$ & \\
\hline & $\begin{array}{l}\text { Could it be an effective low carbon } \\
\text { technology in short- or long-term? }\end{array}$ & \\
\hline \multirow{3}{*}{$\begin{array}{l}\text { Potential risk of CCS } \\
\text { projects and the } \\
\text { corresponding risk } \\
\text { control }\end{array}$} & $\begin{array}{l}\text { What kind of potential risks of CCS/CR } \\
\text { exist in Vietnam }\end{array}$ & \multirow{3}{*}{$\begin{array}{l}\text { To prepare solutions to deal } \\
\text { with potential risks }\end{array}$} \\
\hline & Is it preventing CCS/CR from deployment & \\
\hline & How to control risks effectively & \\
\hline $\begin{array}{l}\text { Influencing factors and } \\
\text { incentives for CCS/CR } \\
\text { deployment in Vietnam }\end{array}$ & $\begin{array}{l}\text { What are the main influencing factors in } \\
\text { CCS/CR deployment in Vietnam }\end{array}$ & $\begin{array}{l}\text { To provide policy-making } \\
\text { recommendations for CCS/CR } \\
\text { development }\end{array}$ \\
\hline
\end{tabular}

